\title{
The Purpose of the Communication Process of Group Activities in the Family Health Strategy
}

\author{
Leticia Silveira Cardoso ${ }^{1}$ \\ Marta Regina Cezar-Vaz² \\ Mara Regina Santos da Silva ${ }^{3}$ \\ Valdecir Zavarese da Costa ${ }^{4}$
}

\begin{abstract}
This study identified the purposes of the communication process in the group activities of the Family Health strategy from the perspective of nurses. Semi-structured interviews were conducted and recorded with 60 nurses and non-participant observation with 19 group activities, analyzed according to qualitative content analysis. Five categories emerged: Health education, Clinical follow-up, Co-responsibilization of patients, Team-Community Interaction, and Work Organization. These categories revealed that the establishment of reciprocal interactions among professionals, patients and families favor health promotion because it encourages the exchange of knowledge among the participants concerning their health experiences.

Descriptors: Communication; Group Processes; Family Health Program; Public Health Nursing; Information Theory.
\end{abstract}

\footnotetext{
${ }^{1}$ RN, Doctoral student in Nursing, Universidade Federal do Rio Grande, RS, Brazil. Scholarship holder of Coordenação de Aperfeiçoamento de Pessoal de Nível Superior (CAPES). E-mail: Isc_enf@yahoo.com.br.

2 RN, Ph.D. in Nursing, Adjunct Professor, Escola de Enfermagem, Universidade Federal do Rio Grande, RS, Brazil. E-mail: cezarvaz@vetorial.net.

${ }^{3}$ RN, Ph.D. in Nursing, Adjunct Professor, Escola de Enfermagem, Universidade Federal do Rio Grande, RS, Brazil. E-mail: marare@brturbo.com.br.

${ }^{4}$ RN, Doctoral student in Environmental Education, Escola de Enfermagem, Universidade Federal do Rio Grande, RS, Brazil. Assistant Professor, Universidade Federal do Pampa, Bagé, RS, Brazil. E-mail: valdecircosta@unipampa.edu.br.
}

Corresponding Author: Leticia Silveira Cardoso Av. Marcílo Dias, 1299/02 CEP 96400-020 Bagé, RS, Brasil E-mail: Isc_enf@yahoo.com.br 


\title{
Finalidade do processo comunicacional das atividades em grupo na Estratégia Saúde da Família
}

\begin{abstract}
Objetivou-se, por este estudo, identificar os sentidos de finalidade do processo comunicacional nas atividades em grupo da Estratégia Saúde da Família, na perspectiva dos enfermeiros. Usaram-se as técnicas de entrevista semiestruturada gravada, com 60 enfermeiros, e de observação não participante, em 19 atividades em grupo, analisadas segundo abordagem qualitativa de conteúdo. Evidenciaram-se cinco categorias: educação em saúde, acompanhamento clínico, corresponsabilização dos clientes, interação equipe/ comunidade e organização do trabalho, permitindo inferir que o estabelecimento de interações de reciprocidade entre profissionais/clientes/família favorece a intervenção promotora da saúde, por estimular a troca de conhecimentos entre os participantes, a respeito de suas experiências de saúde.
\end{abstract}

Descritores: Comunicação; Processos Grupais; Programa Saúde da Família; Enfermagem em Saúde Pública; Teoria da Informação.

\section{Finalidad del proceso de comunicación de las actividades en grupo en la Estrategia Salud de la Familia}

Se objetivó identificar los sentidos de finalidad del proceso de comunicación en las actividades en grupo de la Estrategia Salud de la Familia, en la perspectiva de los enfermeros. Se usó las técnicas de entrevista semiestructurada grabada con 60 enfermeros y de observación no participante en 19 actividades en grupo, analizadas según el abordaje cualitativo de contenido. Se evidenció cinco categorías: Educación en Salud, Acompañamiento Clínico, Corresponsabilidad de los Clientes, Interacción Equipo Comunidad y Organización del Trabajo. Ellos permitieron inferir que el establecimiento de interacciones de reciprocidad entre profesionales, clientes y familia favorece la intervención promotora de la salud por estimular el intercambio de conocimientos entre los participantes al respecto de sus experiencias de salud.

Descriptores: Comunicación; Procesos de Grupo; Programa Salud de la Familia; Enfermería en Salud Pública; Teoría de la Información.

\section{Introduction}

Group activities in the Family Health Strategy (FHS) represent collective opportunities for workers and the object/subject of actions to interact and are ensured by the Brazilian Policy of Primary Health Care $^{(1)}$, which establishes the development of actions directed to atrisk groups to preventively intervene in the control and onset of local community diseases.

The communication process is seen as the main means for the development of these collective activities. This process is developed based on needs and the work process $^{(2)}$, that is, on the needs of the object/subject of action toward whom the work is directed and whose needs are acknowledged by workers to guide their work.

Such a process constitutes nursing practice to the extent communication uni-linearly connects the work actions of the different members of the health team, which is the theme of focus from the perspective of humanization of health care ${ }^{(3)}$.

Humanization that is developed through reciprocal interactions among professionals, patients and families requires constant validation of the content transmitted and received in order to avoid communication noise, which may alter the expected meaning of work. Such validation 
implies the construction of a bidirectional dialogue in which reception, interpretation and communication of content of a message occurs ${ }^{(4)}$. Communication is also affected by factors that go beyond just the verbal and includes movements, facial expressions, and the disposition of objects in the environment where interaction occurs, among others ${ }^{(5)}$.

The communication process within nurses' hospital practice is largely disseminated in the scientific sphere, while research in relation to the primary health care team and to aspects that strengthen the leadership of nursing workers is scarce(6).

It is an aspect that seems a viable option for transforming the work process in the FHS because there are tools recommended for the team's collective work with an emphasis on group activities that can represent the confluence of thinking by workers concerning their actions to (re)construct their relationships within the team and with patients ${ }^{(7)}$.

This construction, from the perspective of workers in the FHS, requires the team to critically discuss and selfreflect upon the individual manner of receiving patients and developing interactive work, both in the verbal and non-verbal expressiveness of the communication process toward the production of health care. Added to it is the opportunity for patients to receive a service that enables them to be heeded according to their unique health needs ${ }^{(8)}$.

This perspective indicates the valorization of discussions concerning the communication process in health because the establishment of bonds of trust between workers and patients is a relevant factor for the success of health work. It is bounded by the judgment of patients concerning the work process constructed in the relationships and interactions of workers in the production of care(9).

Care production, in the sphere of the FHS, still requires workers with more theoretical sensitivity to apply or use interactive instruments, such as the communication process, in order to promote a significant differentiation in their work with families ${ }^{(10)}$

Therefore, acknowledging the needs of objects/ subjects of action lead workers to include the meaning of their work, better yet, the purpose(s) of their work, in the need-object relationship (11). Under such a conception, this study identifies the meanings of the purpose of the communication process produced by the participants of group activities from the perspective of nurses working in the FHS.

This study contributes by giving visibility to the communication process in the FHS in the particular context of group activities aiming to value the interactive work process as a source to solve the health needs of families.

\section{Method}

Study design: Exploratory, descriptive, analytical and cross-sectional(12) of the communication production triggered in the group activities of the FHS.

Study setting: Family health primary care network of the $3^{\text {rd }}$ Regional Health Coordination at Rio Grande do Sul ( $3^{\text {rd }}$ CRS, RS) in the extreme south of Brazil.

Population: 60 nurses of the existing 49 family health units in the data collection period in the 12 cities ascribed to the $3^{\text {rd }}$ CRS, RS, Brazil.

Data collection procedures: First, the existing number of teams in the FHS in the study's region was verified. Then, a formal requirement was sent to the $3^{\text {rd }}$ CRS, RS and to the City Health Departments explaining the study's objectives and ensuring confidentiality of the facilities and individuals. The study was approved by the Research Ethics Committee in the Health Field at the Federal University of Rio Grande (number 02/2004). After consent was gained from the institutions, which provided the names of nurses on each team and addresses of the units, the interviews and observations were scheduled according to the availability of the teams.

Both the scripts of the semi-structured interviews and observations were tested through a pilot-study with a team that did not belong to the selected group.

Data were collected from January to July 2006 through recorded semi-structured interviews that addressed the communication process in the group activities, which included a description of nurses' actions, how they are performed, of the participants and their purposes. The family health teams were selected based on the following criteria: working either within the City Full Management System or Primary Health Care Full Management; being connected to the FHS; having more than six months experience since the teams' creation; professionals having more than six months of experience in the FHS; having all the professionals required in the primary care team; consenting and being available to pursue all the study's stages.

Non-participant, non-systematic and public observations took place between July 2006 and June 2007 during 19 group activities ${ }^{(13)}$. Criteria were established based on information obtained in the interviews. They were: percentage ratio of the number of family primary 
health care units in each city; coverage of urban and rural populations; integration among professionals and between them and the community; and adherence and persistence in performing group activities.

Three pairs of researchers distributed throughout the nine Family Health Units selected carried out observations. The researchers recorded the work process of the group activities of 17 teams. The purpose of records was to take notes on the dialogues produced by the participants, their movements, and material resources to develop the activity, characteristics of the environment and of the participants.

The content ${ }^{(13)}$ of the interviews and observations were qualitatively analyzed using the software Nvivo 7.0. The following non-exclusive categories emerged from the interviews: "Health Education", "Clinical Follow-up", "Co-responsibilization of Patients", "Team-Community Integration", and "Work Organization", which were later investigated in the observational records of the group activities of the FHS.

At the end of each interview and observation record, fictitious numbers were assigned to the city $(C)$, the team $(\mathrm{T})$, and the nurse $(\mathrm{N})$, in compliance with the standards and guidelines that regulate research with human subjects established by Resolution 196/96 of the National Council of Health.

\section{Results}

The meanings of the purpose of the communication process triggered in the work of group activities constitute empirical categories extracted from the reports of the interviewed nurses and identified in the observation records of the group activities of the FHS.

\section{Health Education}

A total of 48 reports of 60 interviewed nurses and 13 records of the 19 observed group activities composed this category, characterizing the communication process as an instrument to disseminate health information and knowledge. For that, nurses used expressions such as "educate (C02 T03 N05), guide (C01 T01 N01), engender awareness (C07 T06 N09), inform (C12 T29 N33), clarify (C04 T07 N18), teach (C02 ET01 N02)", among others to explain the developed actions. Hence, they translate the communication process only in its verbal representation, that is, by the use of language/speech in a unidirectional production of health education in relation to the meaning of health promotion.

\section{Clinical Follow-up}

This category comprises 15 reports of nurses and 14 observations that conceive of the communication process as a way to capture information concerning the health condition of patients. The terminology utilized expresses actions such as "accompanying (C11 T47 N55), controlling (C08 T25 N29), monitoring (C12 T38 N40), and caring (C03 T08 N12)", among others. These indicate the meaning 'clinical disease prevention' in a uni-directional production predominantly constituted by non-verbal communication.

\section{Co-responsiabilization of Patients}

Nurses refer to this category in 12 interviews and the researchers identified it in four group activities, clarifying the communication process as part of a health promotion sphere enabling patients to become autonomous. This aspect is reported by nurses through the use of expressions such as "identification of resources (C05 T13 N23), participation and dissemination of team activities (C06 T15 N27), self-care (C09 T18 T23)", among others. For that, the professionals use verbal and non-verbal resources produced during the group activities.

\section{Team-Community Integration}

This category obtained 11 reports of the interviewed nurses and four observations, showing that the communication process, both verbal and non-verbal, in its meaning of 'health promotion' is denoted through expressions such as: "approximate (C02 T04 N04), integrate (C06 T10 N11), establish bonds between the community and the team's professionals (C10 T18 N20"), among others in the development of group activities.

\section{Work Organization}

The communication process in nine reports and 18 observations presents the meaning 'clinical disease prevention', given the reference to actions that encourage the reduction of community rates of morbidity and mortality in the work of the FHS team such as: "schedule in advance (C05 T08 N09), identification of community problems (C03 T05 N07) planning groups activities (C07 T11 N16), weighing children (C11 T47 N47), medication distribution (C09 T18 N30), distribution of condoms (C01 T03 T01), distribution of contraceptives (C02 T03 N07)" among others, leading to the optimization and qualification of the productive process through verbal and non-verbal communication triggering group activities. 


\section{Discussion}

According to nurse reports, the production that emerges from the communication process in the group activities of the FHS reveals that health education is the final purpose of the actions developed. They are instruments to disseminate health information and knowledge.

The terminology "education" in the narrative of these nurses includes informal development ${ }^{(14)}$, since the exchange of experiences occurs in a collective environment of interaction and the verbalized content seeks to enable the participants to preventively intervene in the health sphere.

In this context, the work of nurses in the FHS group activities within the category 'health education' shows the development of actions impregnated with the intention to promote health through the exchange of knowledge, informing those involved in the communication process.

The exchange of knowledge accrues from the individual interpretation process that is conditioned by access to health information for the development of actions that qualify the skills of individuals to intervene and interact in organized collectives to promote health(15).

Promoting health through communication reduces the feelings of anguish and threat patients experience when facing different or even routine situations in their bio-psycho-social context as they access information concerning self-care actions and receive emotional and motivational support during educational actions and when receiving guidance(16).

The observed communication process revealed that such actions converge in a professional practice focused on the needs or organic alterations of patients. It strengthens the epidemiological health model through the achievement of the ministry goals to cover the population and concomitantly reveals distortions between what nurses verbalize and what researchers observe.

Nevertheless, the education constructed by the connection between workers and patients in the FHS is a method to grasp the cultural and social differences of individuals and their families. Nurses can use such differences to acquire knowledge and skills to better deal and cure diseases in the community ${ }^{(17)}$.

The direction of the communication process reported by the studied nurses during the development of group activities shows that the message produced in health education, the main purpose, is unidirectional. The reported actions demonstrate a non-reciprocal, expositive system: only the interlocutor-the health professionalverbally transmits the content disseminated in the group activities while patients are mere momentary receptors of such information. Afterwards, the users also become transmitters of content shared by professionals in the group activities in the spectrum of intra-community relations promoted by the patients.

The interactive worker-patient-family process conforms to non-formal education in which the produced knowledge is linked to the social routine of patients, who compose a collective of common needs and interests ${ }^{(18)}$.

Another contribution revealed in the study is related to the way information represented by the category 'clinical follow-up' is captured. This category is composed of records of the non-verbal communication process, which includes information such as blood pressure, glucose, height, and weight measurements, among others. Such records correspond to measurements taken from what is tactile, the language of touch perspective, concerning the characteristics of patients ${ }^{(5)}$.

According to the nurses' perceptions, health records are intended to evidence the performed work in order to produce information to formulate health indicators and follow-up patients. The follow-up of patients is performed based on health records, an instrument used in the decision-making process of workers during the FHS activities ${ }^{(19)}$.

The possibility of thinking through the purpose of the work process expresses the humanized bond workers establish with patients to develop their actions and permit them to enable clients to have an improved quality of life(11).

In this dimension, clinical follow-up as a way to communicate actions, one comes to the limits of the work process itself from the technical application of evaluation procedures that produce a dialog based on the objectivity of the clinical-pathological situation of clients.

The categories 'co-responsibilization of patients' and 'community-team integration' are presented as the purpose of the communication process triggered in the group activities, related to the improvement of the community's and the FHS professionals' competencies. Such competencies comprise the knowledge disseminated by the patients in the community concerning the work process performed in the FHS based on information received from professionals during the group activities.

In the sphere of the production of competencies as one of the purposes of the communication process, the 
diffusion and dissemination of information are related to verbal and non-verbal resources used by the interlocutors to transmit and receive the message content ${ }^{(18)}$.

Communication as 'the ability to dialog' among the team's workers and between workers and patients allows the work process to become an instrument to encourage the patients' co-responsibility and problemsolving capacity to effectively achieve that purpose.

Therefore, non-verbal communication constitutes a significant aspect of the establishment of bonds between patients and workers, which can be decisive in encouraging adherence to the FHS group activities since trust is the base for a (un)successful relationship ${ }^{(9)}$.

The construction of a reciprocal communication relationship is only possible when dialogue is not monopolized, that is, when interlocutors listen, too ${ }^{(16)}$.

The category 'work organization', an empirical category identified in this study, represents, according to the perception of nurses, the optimization and qualification of health production concerning the purposes of the communication process triggered in the group activities, because it more easily reaches a collective of patients with information related to disease prevention. Hence, verbal communication encompasses aspects of care necessary to maintaining the health of patients. Non-verbal communication represents the monitoring of the vital signs of this collective, the different groups, composed of common interests.

The observational records of the communication processtriggered by theFHSgroupactivitiesdemonstrated that the communication process in the nurses' practice is primarily focused on disease prevention, which is contrary to these professionals' reports that classify health education as the main purpose.

The organization of actions within Family Health is focused on the individual and the family, designed to prevent disease and also alleviate the suffering related to them while coping with a disease situation(17). The work process is conditioned by the production of material conditions and health needs of the subjects of action, bringing together the needs and capabilities of those who seek through their work to satisfy the patients' needs. This practice of professionals, which has a meaning of 'disease risk prevention', becomes the differential of work in primary health care, since such a practice enables one to reduce the incidence of pathological situations in the community. In this context, the authors identify the capacity of triggering individual or collective reflections as the purpose of the work process from the perception of nurses and physicians ${ }^{(17)}$.
Hence, this study is limited to the understanding of meanings of purpose of the communication process triggered in the FHS group activities without the intention to dwell on the details of disseminating health information and knowledge. However, the theme of communication, the study's setting itself, and the group activities by themselves represent a complex set to investigate the diffusion and dissemination of health information and knowledge, which can become an object of interest of further research.

\section{Conclusion}

The communication process in the FHS group activities displays dichotomies between what nurses reported and what researchers observed in relation to the purposes of the work process. The workers have theoretical knowledge concerning the communication process, however, the application of this instrument in practice, an instrument with the potential to go beyond the organization of work, is limited. Hence, they become intertwined in the possibility of conscious embodiment of the communication process as a means to differentiate health work.

The exchange of knowledge through the communication process concerning health experiences, which are produced in the particularities of the relationships existing among the environment, primary health care and the object/subject of actions, corroborates the establishment of reciprocal interactions, strengthening health promotion interventions.

Based on this understanding, this study presents the need for managers of primary health care services to make available not only opportunities for continuing education to advance in the production of knowledge but also to include in the work process itself actions to encourage the teams' workers to pursue self-knowledge to improve the collective mode of producing health and make it more decisive.

\section{References}

1. Ministério da Saúde (BR). Secretária de Atenção à Saúde. Departamento de Atenção Básica. Política Nacional de Atenção Básica. 4. ed. Brasília: Ministério da Saúde; 2007.

2. Marx K. O capital. 7a ed. Rio de Janeiro: Guanabara, 1982.

3. Machado MMT, Leitão GCM, Holanda FUX. O conceito de ação comunicativa: uma contribuição para a consulta de enfermagem. Rev. Latino-Am. Enfermagem. 2005 
set-out; 13(5):723-8.

4. Martino LMS. Teoria da Comunicação: ideias, conceitos e métodos. Petrópolis (RJ): Vozes;2009.

5. Silva MJP. Comunicação tem remédio: a comunicação nas relações interpessoais em saúde. $3^{a}$ ed. São Paulo: Edições Loyola; 2005.

6. Spagnuolo RS, Pereira MLT. Healthcare practices in nursing and communication: a review of the literature. Ciênc Saúde Coletiva 2007 Dez; 12(6):1603-10.

7. Fortuna CM, Mishima SM, Matumoto S, Pereira MJB. Team work in a family health care program: the team process concept and operational teams. Rev. Latino-Am. Enfermagem. 2005 abr; 13(2):262-8.

8. Oliveira A, Neto JCS, Machado MLT, Souza MBB, Feliciano $A B$, Ogata MN. A comunicação no contexto do acolhimento em uma unidade de saúde da família de São Carlos, SP. Interface - Comunic., Saúde, Educ. outdez 2008;12(27):749-62.

9. Valentim IVL, Kruel AJ. A importância da confiança interpessoal para a consolidação do programa de saúde da família. Ciênc Saúde Coletiva ago-set 2007;12(3):3-22.

10. Oliveira RG, Marcon SS. Working with families within the famly health program: nurses practice in Maringá-Paraná. Rev Esc Enferm USP. abr-maio 2010;41(1):149-54.

11. Cezar-Vaz MR, Muccillo-Baisch AL, Soares MCF, Soares JFS, Costa VZ, Keber NPC, et. al. System of meaning on the goal of the work on family health: a qualitative approach. Rev ESC Enferm USP. dez 2009;43(1):915-22.

12. Flick U. Introdução à pesquisa qualitativa. $3^{a}$ ed. Porto Alegre: Artmed; 2009.

13. Silverman D. Interpretação de dados qualitativos: métodos para análise de entrevistas, textos e interações. Porto Alegre: Artmed; 2009.

14. Gohn MG. Educação não formal, participação da sociedade civil e estruturas colegiadas nas escolas. Ensaio: Aval. Pol. Públ Educ. jan-mar 2006;14(50):27-38.

15. Méndez JBJ. Acesso a la información y equidad en salud. Rev Cubana Salud Pública. 2007 dic; 33(3):1-8.

16. Martínez $\mathrm{OH}$. Hacia uma comunicacion efectiva y humanista em ambios de salud. Rev Haban Cienc Méd Habana. 2008 ene-mar; 7(1):1-10.

17. Cezar-Vaz MR, Cardoso LS, Bonow CA, Sant'Anna CF, Sena J. Conhecimento clínico do enfermeiro na atenção primária à saúde: aplicação de uma matriz filosófica de análise. Rev Texto Contexto Enferm. janmar 2010;19(1):17-24.

18. Pessoni A. Comunicação \& Saúde: parceria interdisciplinar. São Paulo: Mídia Alternativa;2006.

19. Almeida MCV, Cezar-Vaz MR, Figueiredo PP, Cardoso LS, Sant'Anna CF, Bonow CA. Registros em saúde como instrumento no processo de trabalho das equipes de Saúde da Família. Cienc Cuidado e Saúde. jul-set 2009; 8(3):305-12. 